\title{
Repetisi mengenai Keputusasaan Pemazmur dalam Menantikan Pertolongan Allah: Eksegesis Mazmur 13
}

\author{
A Repetition of the Psalmist's Despair in Waiting for God's Help: Exegesis of Psalm 13
}

Author:
- Farel Yosua Sualang ${ }^{1}$
- Jani
Affiliation:
1Sekolah Tinggi Teologi
Injili Indonesia Yogyakarta
sualangfarel@gmail.com
25ekolah Tinggi Teologi
Injili Indonesia Yogyakarta
jannilewi@gmail.com

Dates:
Submitted:
27 January 2021
Accepted:
1 April 2021
Published:
17 May 2021

DOI:
$10.46494 / p s c . v 17 i 1.127$

\section{Copyright:}

(C) 2021. The Authors. Licensee: PASCA. This work is licensed under the Creative Commons Attribution-ShareAlike 4.0 International License.
Abstract: Psalm 13 is a repetition which ends by moving to serenity as part of God's help. The method used is qualitative with a hermeneutic approach, especially poetry Genre. This study aims to explain a repetition of the psalmist as an emphasis on supplication to God which has an impact on theological values. This article finds the psalmist's complaint three times repeated; first, the expression of the psalmist's longsuffering despair, the second the psalmist sincerely hoped for deliverance from God which could soon be realized. Then there is a repetition of the salvation of God Himself, who saves from the world of death, illuminates the eyes (verse 3), and the third does good things (v. 5b).

[Mazmur 13 merupakan reptisi yang diakhiri dengan bergerak kepada ketenangan sebagai peran dari pertolongan Allah. Metode yang digunakan adalah kualitatif dengan pendekatan hermeneutika, khususnya sastra puisi. Penelitian ini bertujuan untuk menjelaskan suatu repetisi dari pemazmur sebagai penekanan terhadap permohonan kepada Allah yang berdampak kepada suatu nilai-nilai teologis. Artikel ini menemukan adanya pengulangan keluhan pemazmur sebanyak tiga kali; pertama, ekspresi keputusasaan pemazmur yang menderita berkepanjangan, kedua Pemazmur sungguh mengharapkan pembebasan dari Allah yang dapat segera terwujud. Lalu terjadi repitisi kembali tentang penyelamatan Allah sendiri, yang menyelamatkan dari dunia kematian, menerangi mata (ayat 3), dan ketiga melakukan hal-hal yang baik (ay 5b).]

Research Contribution: This research contributes to institutions that provide Christian religious education in structuring and making actual curricula and responding to the challenges of meeting the needs of the millennial generation, who depend a lot on technology.

Keywords: Psalm, Lamentations, hymn, repetition, God's help.

\section{Pendahuluan}

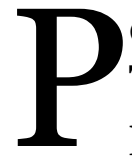
enulis Mazmur banyak mengungkapkan permohonannya kepada Tuhan untuk menggambarkan pengalamannya tentang penderitaan dan keputusasaan. Ia menggambarkan suatu kelegaan dan kesembuhan secara spiritual untuk beralih kepada Allah. Christenson menunjukan bahwa materi-materi Mazmur ratapan memberikan antisipasi mengenai penanganan depresi bahwa keyakinan dan praktik 
agama memiliki dampak positif pada gejala depresi klinis modern melalui kajiannya terhadap interpretasi Mazmur 31 dan Mazmur 102. ${ }^{1}$ Bahkan menurut Lewis Hall, Mazmurmazmur ratapan merupakan sumber yang kaya bagi seorang Kristen yang menderita. Seseorang dapat melatih spiritualnya secara disiplin untuk diubah oleh Tuhan. ${ }^{2}$ Nampaknya, penyelidikan Lewis Hall sangat tematis, ia menghubungkan teks-teks Perjanjian Lama dan keteladanan Yesus dalam teks-teks Perjanjian Baru mengenai ratapan, lalu diintegrasikan kepada literatur-literatur Psikologi. Sekalipun, suatu kajian eksegesis Mazmur ratapan menjadi bagian penting untuk menemukan adanya kemungkinan dua alur yaitu dari suatu ratapan kepada pujian ataupun suatu ratapan kepada nasihat.

Pemazmur dapat meratapi, mengaku, dan bertobat, serta menghubungkan dirinya kepada perjanjian dengan Allah. Interpretasi Martin dengan menggunakan analisis retoris mampu menunjukan suatu paralelisme Chiastik Mazmur 130 untuk menemukan adanya hubungan yang diperlukan antara ratapan dan harapan. ${ }^{3}$ Sub-genre Mazmur Ratapan merupakan hal yang paling umum ditemui dalam kitab Mazmur, dimana ada dua kategori, yaitu: Mazmur Ratapan Pribadi yang terdiri dari pasal 3-7, 9-11, 13, 16, 17, 22, 25-28, $31,35-36,38-40,42-43,51-52,54-57,59,61-$ $64,69-71,77,86,88,94,102,109,120,130$, 140-43, dan Mazmur komunal yang terdiri dari pasal 12, 14, 44, 53, 58, 60, 74, 79-80, 83, 85, $90,106,108,123,126,137) .^{4}$

\footnotetext{
${ }^{1}$ Randall M. Christenson, "Parallels between Depression and Lament," The journal of pastoral care \& counseling : JPCC 61, no. 4 (2007): 306.

${ }^{2}$ M. Elizabeth Lewis Hall, "Suffering in God's Presence: The Role of Lament in Transformation," Journal of Spiritual Formation and Soul Care 9, no. 2 (2016): 232. ${ }^{3}$ Lee Roy Martin, "Lament and Hope in Psalm 130," Pharos Journal of Theology 100, no. 1 (2019): 1-12. ${ }^{4}$ Martus Adinugraha Maleachi, "Karakteristik Dan Berbagai Genre Dalam Kitab Mazmur,” Veritas : Jurnal Teologi dan Pelayanan 13, no. 1 (2012): 131-132.
}

Di antara kedua kelompok Mazmur ratapan, ada doa tersingkat bagi keselamatan, namun memberikan suatu permohonan pendek, serta dipenuhi dengan perasaan emosional yang efektif yaitu Mazmur 13. May setuju bahwa Mazmur 13 merupakan tipe "a parade example" (mis, "ratapan pribadi") dan menulis bahwa pemazmur mengandung "elemen-elemen esensial (ratapan-ratapan pribadi)" yang komprehensif, sehingga ia memaparkan dalam penemuannya bahwa Mazmur 13 sebagai suatu ratapan pribadi yang memberikan representatif bagi Mazmur-mazmur ratapan pribadi lainnya. ${ }^{5}$ Dalam perkembangannya, Wendland memberikan suatu interpretasi dengan memakai analisa terjemahan Mazmur 13 yang dihubungkan dengan bentuk lirik, isi dan fungsi di dalam kepentingannya kepada bahasa Chicewa di Afrika. Ia menegaskan bahwa bahasa ibu dapat memaknai secara tepat Mazmur ratapan pribadi. ${ }^{6}$

Dari sisi yang lain, Beckket memperhatikan bahwa interpretasinya terhadap Mazmur 13 bertujuan untuk membangun suatu 3 (tiga) pola rekonsiliasi (krisis ke arah keluhan, keluhan ke arah permohonan dan permohonan ke arah pujian), bukan hanya antara Allah kepada manusia namun kepada sesama, khususnya pada lingkup para pelayan dalam komunitas gereja. ${ }^{7} \quad$ Ia nampak memberikan suatu perspektif yang diintegrasikan dari teologi pastoral ke arah psikologis. Uniknya, Prinsloo menggunakan pendekatan fungsionalantropologis dan kanonik terhadap teks Mazmur 13 dan teks Assyrian Elegy (R 9) untuk menunjukkan bahwa kedua teks ini memiliki kesamaan terhadap keterlibatan seseorang

\footnotetext{
5James L May, "Expository Articles Psalm 13," An Epsilon of Room, II (2011): 279-282.

${ }^{6}$ Ernst R. Wendland, "Poeticizing the Psalter in an African Language: From Poetry into Poetry, With Special Reference to Psalm 13- 'How Long, O Lord...!,"' Open Theology 2, no. 1 (2016): 165-178.

${ }^{7}$ Joshua Beckett, "Lament in Three Movements: The Implications of Psalm 13 for Justice and Reconciliation," Journal of Spiritual Formation and Soul Care 9, no. 2 (2016): 207-218, https://doi.org/10.1177/193979091600900206.
} 
dalam meratap. Prinsloo menegaskan bahwa kedua teks tersebut memberikan suatu pengalaman penderitaan yang diungkapkan

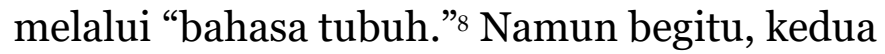
teks memberikan suatu konsekuensi yang berbeda. Mazmur 13 memberikan suatu harapan yang berasal dari Allah, sedangkan teks Assyrian Allegy (R9) hanya memberikan suatu mimpi, dimana ada suara wanita yang menderita dari "tanah tanpa harapan" (R9). Memang sampai saat ini masih sedikit literatur yang membahas tentang suatu penemuan terhadap repetisi / pengulangan sebagai penekanan kepada nilai teologis dari struktur sastra Mazmur 13.

Jika mempertimbangkan secara khusus pentingnya interpretasi Mazmur 13 sebagai sub-genre mazmur ratapan pribadi dalam keseluruhan struktur puisinya yang lengkap, maka menarik bagi peneliti untuk memberikan suatu pendekatan eksegesis terhadap Mazmur 13 sebagai sub genre mazmur ratapan pribadi. Lalu, bagaimana cara menemukan Mazmur 13 yang bernuansa repetisi berdasarkan struktur sastranya? Penelitian ini bertujuan untuk memahami suatu repetisi dari peran pemazmur sebagai penekanan terhadap suatu permohonan kepada Allah yang berdampak kepada suatu nilai-nilai teologis.

\section{Metode}

Metode yang digunakan dalam penelitian ini adalah metode kualitatif dengan pendekatan hermeneutik (Interpretative design): Eksegesis. $^{9}$ Secara khusus peneliti menggunakan analisis sastra puisi dengan memperhatikan analisis teks dari kata-kata

\footnotetext{
${ }^{8}$ Gert T. Prinsloo, "Suffering Bodies - Divine Absence:

Towards a Spatial Reading of Ancient Near Eastern Laments with Reference to Psalm 13 and an Assyrian Elegy (K 890)," Old Testament Essays 26, no. 3 (2013): 773-803.

${ }^{9}$ Sonny Eli Zaluchu, "Strategi Penelitian Kualitatif Dan Kuantitatif Di Dalam Penelitian Agama," Evangelikal: Jurnal Teologi Injili dan Pembinaan Warga Jemaat 4, no. 1 (2020): 35 .
}

kunci dari bahasa Ibrani yang mencakup pada uraian teks Biblia Hebraica Sturtgantsia (BHS), struktur Mazmur (khususnya memperhatikan adanya paralelisme), bahasa puitisnya (bahasa perbandingan seperti simile, metafora dan lain-lain atau bahasa penggantian seperti metonomia), sub-genre dari Mazmur tersebut (kesamaan literatur, setting dan tujuan), konteks historis, serta makna teologis. ${ }^{10}$

\section{Pembahasan}

\section{Bentuk Sastra}

Dalam pandangan konvensional, Mazmur 13 termasuk dalam kategori Mazmur "ratapan" atau "permohonan," khususnya jenis literatur yang dikenal sebagai "ratapan pribadi." Menariknya Delitzsch menunjukkan bahwa kolektor Mazmur menempatkan pasal 12 dan 13 bersama-sama sebagai Mazmur ratapan (meskipun pasal 12 adalah "ratapan umum," daripada ratapan pribadi). ${ }^{11}$ Klasifikasi Mazmur ini sebagai "ratapan" yang telah menjadi pokok kritikan keras dari para pakar kritik bentuk. Bahkan para pakar sependapat bahwa Mazmur 13 yang memberikan struktur taksonomi dan ratapan pribadi yang telah mengeluarkan peringatan mengenai terminologi ini. Anderson menyarankan pandangan pesimis dan kehidupan, keluhan mengenai mengasihani diri sendiri, atau 'meratapi tragedi yang tidak dapat dikembalikan, yang merupakan karakteristik dan sebuah nyanyian. Ia ingin membedakan antara "lamentation" dan "lament," yang mana sebagian besar mazmur ratapan memenuhi syarat sebagai laments, di mana menyatakan harapan adalah perbedaan utama dari lamentation. ${ }^{12} \quad$ Untuk memperbaiki

\footnotetext{
${ }^{10}$ Tremper Longman III, How to Read The Psalms (Illinois: InterVarsity Press, 2009), 13, 103, 151. Maleachi, "Karakteristik Dan Berbagai Genre Dalam Kitab Mazmur," 135-136.

${ }^{11}$ Franz Delitzsch, Biblical Commentary on the Psalms (Vol. 3) (Grand Rapids: William B. Eerdman's, 1982), 199.

${ }^{12}$ Arnold A Anderson, The Book of Psalms V. 1 Introduction and Psalms 1-72, ed. Roland E. Clements
} 
kesalahpahaman seperti itu, Mays ingin mengidentifikasi jenis Mazmur 13 sebagai liturgi "doa untuk menolong seorang individu."13 Demikian juga, Westermann secara hati-hati mencatat bahwa dalam banyak ratapan, permohonan mengikuti keluhan, dengan demikian, secara bersama-sama, bagian komponen merupakan doa/ ratapan. Pada saat lain, ia mencatat bahwa kadangkadang sulit untuk membedakan antara ratapan komunal dan individual. Bagaimanapun, umumnya, "Keluhan terhadap Allah tidak memiliki peran dominan dalam ratapan individu seperti dalam ratapan umat."14 Sedangkan, Staton memilih untuk "doa keluhan," Ia cenderung memilih istilah "keluhan" untuk "ratapan." Hal ini dikarenakan "ratapan" sudah menjadi istilah teknis untuk "nyanyian pemakaman" (misalnya, 2 Samuel 1:17-27). Selain itu, mereka berpendapat bahwa "keluhan" hanyalah sebuah deskripsi yang lebih tepat dari bentuk "ratapan."15

Kraus ingin meninggalkan konsep ratapan seluruhnya dan mengklasifikasikan Mazmur 13 sebagai "lagu doa." Ia melihat pemazmur terutama sebagai "pemohon," dan ia menegaskan bahwa ia tidak meratap atau mengeluh. Sebaliknya, "ia terbuka menyatakan penderitaannya di hadapan TUHAN dan berdoa untuk intervensi-Nya. Karena itu, tradisi Ibrani menyebut lagu doa sebagai hlpt."16

Broyles juga berpendapat bahwa istilah "ratapan" terlalu luas. Pada kenyataannya, ada dua jenis ratapan, yang mewakili dua jenis yang sama sekali berbeda: "ratapan kepada Tuhan,"

(London: Oliphants Marshall, Morgan \& Scott, 1977), 128.

${ }^{13}$ James Luther Mays, Psalms (Louisville: Westminster John Knox Press, 2011), 21. May, "Expository Articles Psalm 13",280.

${ }^{14}$ Claus Westerman, Praise and Lament in the Psalms (Atlanta: Westminster John Knox Press, 1981), 183.

${ }^{15}$ Cecil P. Staton Jr, “'How Long, O Yahweh?' The Complaint Prayer Of Psalm 13," Faith and Mission 07, no. 02 (1990): 61. dan "ratapan yang bukan kepada Tuhan." Di dalam ratapan kepada Tuhan, predikatpredikat Tuhan tidak dipuji, tetapi pemazmur mengucapkan ratapannya di masa lalu dan sekarang dalam bentuk keluhan, dan baru kemudian memanggil-Nya berdasarkan watak dan tindakan-Nya. Bagimanapun, di dalam ratapan yang bukan kepada Tuhan, "predikatpredikat Tuhan ... menegaskan pujian kepada Tuhan.” Di dalam ratapan kepada Allah, Allah pada akhirnya bertanggung jawab atas penderitaan yang digambarkan.” Broyles mengklasifikasikan Mazmur 13 sebagai ratapan kepada Tuhan untuk berusaha keras menjelaskan penegasan akan kepercayaan dalam ayat $6 .{ }^{17}$

Mowinckel menentang aliran konsensus para pakar dalam perdebatan atas Mazmur 13 sebagai "mazmur ratapan nasional." Ia berpendapat bahwa meskipun tampaknya ditulis dari perspektif individu, dalam kenyataannya, Mazmur 13 bersifat Mazmur nasional (umat). Oleh karena itu, tidak diragukan lagi bahwa Mazmur ini diklasifikasikan sebagai "ratapan kerajaan," di mana penderitaan pribadi raja melambangkan bencana nasional dan politik. ${ }^{18}$ Sayangnya, Mowinckel tidak memberikan kriteria yang masuk akal untuk membedakan antara ratapan individu dan ratapan nasional. Mungkin saja mazmur ini memang telah dikembangkan penggunaannya di jemaat dalam konteks ibadah, namun tidak ada bukti kritik bentuk yang mana tujuan ini adalah motivasi aslinya. Akhirnya, argumen ini tidak memiliki kekuatan dan gagal menjelaskan bagaimana perbedaan penting antara bentuk-bentuk mempengaruhi penafsiran akan isinya. Dari penjelasan-

\footnotetext{
${ }^{16}$ Hans-Joachim Kraus, Psalms 1-59: A Continental Commentary (Minneapolis: Fortress Press, 1993), 213.

${ }^{17}$ Craig C Broyles, The Conflict of Faith and Experience in the Psalms: A Form-Critical and Theological Study, David J. A (Sheffield: A\&C Black, 1989), 51.

${ }^{18}$ Sigmund Mowinckel, Psalm Studies, Volume 1

(Atlanta: Society of Biblical Literature, 2014), 225.
} 
penjelasan di atas, menurut peneliti, tampaknya masuk akal jika mengklasifikasikan Mazmur 13 sebagai ratapan pribadi (seperti pandangan Delitzsch dan tokoh-tokoh konvensional lainnya).

\section{Setting}

Meski Mazmur 13 bisa saja telah digunakan secara umum dalam upacara di Bait Allah, 19 namun aslinya pemazmur mengekspresikan keluhan individunya (bukan komunal). Ada kesepakatan umum di kalangan para sarjana bahwa pemazmur mengalami kesedihan pribadi yang mendalam ketika musuhmusuhnya mengelilinginya dan telah mengangkat atas dalam perjuangan.

Broyles menunjukkan bahwa ayat 4 menunjukkan bahwa pemazmur hampir mati, kemungkinan dikarenakan oleh penyakit yang berkepanjangan. ${ }^{20}$ Kraus setuju bahwa "pemohon" hampir mati karena penderitaan yang berkepanjangan, tetapi dia menegaskan tidak ada cara untuk mengetahui sifat penderitaannya itu mengacu pada penyakit fisik seperti pandangan Broyles di atas. Menurut Kraus, "keadaan yang sukar di mana pemohon dari mazmur mengucapkan keluhannya ini lebih mengacu pada keterpisahan dari Allah, yaitu, ia mengalami murka Allah."21 Di sisi lain, Craigie menunjukkan bahwa keadaan yang sukar yang dialami pemazmur "mungkin adalah rasa takut dan kedekatan kematian, disebabkan mungkin oleh penyakit serius."22

\section{Struktur Mazmur 13}

Jika mempertimbangkan struktur Mazmur 13, maka hal pertama yang harus ditentukan

\footnotetext{
${ }^{19}$ Craigie and Marvin, Word Biblical Commentary, Psalm 1-50, Volume 19 (Michigan: Zondervan Publishing, 2018), 141.

${ }^{20}$ Broyles, The Conflict of Faith and Experience in the Psalms: A Form-Critical and Theological Study, 184.

${ }^{21}$ Kraus, Psalms 1-59: A Continental Commentary, 213.

${ }^{22}$ Craigie and Marvin, Word Biblical Commentary, Psalm 1-50, Volume 19, 142.
}

adalah apakah mazmur ini memiliki atau tidak struktur strophic. ${ }^{23}$ Dalam rangka untuk mengkonfirmasi struktur strophic, peneliti harus memperhatikan pengaturan irama (metrical) ayat. Anderson mencatat bahwa Mazmur 13 memiliki irama tidak teratur. ${ }^{24}$ Kraus juga menegaskan tidak ada cara untuk membuktikan organisasi strophic, karena ada sebuah "irama kegelisahan." Dia melihat pola 4 +4 dalam ayat-ayat 1 dan 3 , pola $4+3$ dalam ayat 2 dan 4 , dan pola $3+3$ dalam ayat 5 .

Delitzsch mengusulkan struktur format tiga bait, yakni; ayat 2-3, 4-5, 6, namun ia tidak memberikan bukti struktural untuk itu. Pendapatnya lebih didasarkan atas isi Mazmur. Bait pertama (ay. 2-3) berisi pengaduan dan intensitas putus asa, bait kedua (ay. 4-5) berisi urgensi akan ketenangan, dan bait ketiga (ay. 6) berisi rasa percaya diri yang damai. ${ }^{25}$ Tampaknya Delitzsch telah benar memahami gerakan dan kemajuan mazmur, namun begitu "bait" adalah istilah teknis, sehingga mungkin lebih baik untuk berbicara tentang tiga "gerakan" dalam Mazmur 13. Pada dasarnya struktur Mazmur ini dibagi seperti berikut: ay. 1-2 adalah "deskripsi masalah," ay. 3-4 adalah "permohonan bagi pertolongan," dan ay. 5-6 merupakan "pujian kepada Tuhan." Dalam kemajuan Mazmur, ia melihat sistem teologis di mana "bagian yang mengandung urutan komponen yang masing-masing memainkan peran dalam doa sebagai suatu tindakan iman." ${ }^{26}$

Gerakan pertama terdiri dari the lament proper. Westermann menunjukkan bahwa struktur dasar dari sebuah ratapan formal terdiri dari tiga bagian: Kau (Allah), aku (pemazmur), dan

\footnotetext{
${ }^{23}$ Kent Sparks, "The Psalm: Strophic Structure and Theological Commentary," Journal of Near Eastern Studies 66, no. 3 (2007): 210-212, https://doi.org/https://doi.org/10.1086/521760.

${ }^{24}$ Anderson, The Book of Psalms V. 1 Introduction and Psalms 1-72, 128.

${ }^{25}$ Delitzsch, Biblical Commentary on the Psalms (Vol. 3), 199.

${ }^{26}$ James Luther Mays, Psalms, 279. 
mereka (musuh). ${ }^{27}$ Nampaknya, Mazmur ratapan pibadi dan komunal menunjukan adanya hubungan timbal bail antara Allah, Pemazmur dan Musuh sebagai suatu lingkup yang tidak pernah terpisahkan. ${ }^{28}$ Tabel berikut ini memberikan penjelasan terhadap pernyataan di atas.

Tabel 1. Hubungan antara Allah, Manusia dan Musuh dalam Mazmur Ratapan

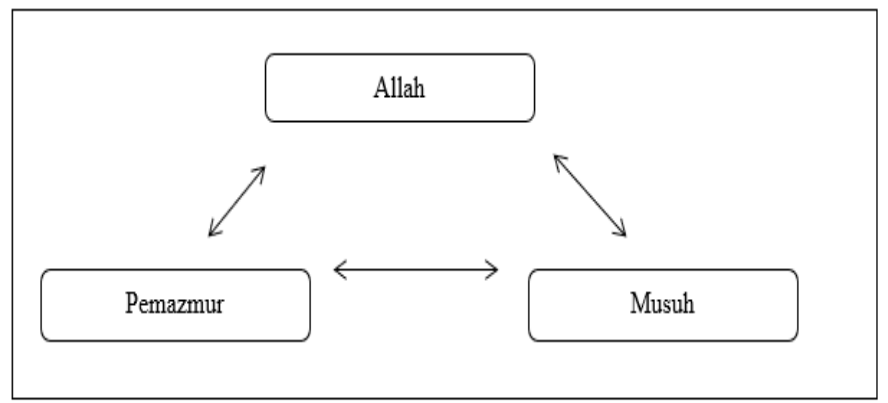

Ini sama seperti apa yang diperhatikan dalam ay. 2-3, yang terdiri dari empat klausa עַרדאָָנָה 'ad-'ānāh. Gerakan kedua merupakan permohonan. Ada tiga kata kerja penting yang digunakan di sini untuk meminta campur

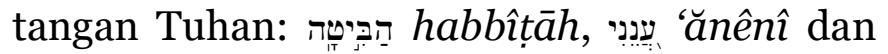
הָאיָירה hầîâh ("ingatlah / consider," "jawablah / "answer,"” dan "terangilah / illuminate").

Ada tiga kemungkinan yang mungkin terjadi jika Tuhan tidak campur tangan: (1) pemazmur akan "tidur atau mati," (2) musuhnya akan berkata, "Aku telah mengalahkan dia," dan (3) musuh-musuhnya akan bersukacita karena ia telah jatuh. Gerakan ketiga mengekspresikan iman yakin pemazmur. Dia menegaskan kepercayaannya kepada Tuhan, mengantisipasinya dengan syukur dan pujian untuk pembebasan yang memberikan dasar untuk pujiannya. Oleh sebab itu, Struktur gramatik Mazmur 13:1-6 dapat diperhatikan pada garis besar eksegesis di bawah ini:

A. Pembukaan (ay.1)

\footnotetext{
${ }^{27}$ Westerman, Praise and Lament in the Psalms, 169.

${ }^{28}$ W. Dennis Tucker, "Is Shame a Matter of Patronage in the Communal Laments?," Journal for the Study of the Old Testament 31, no. 4 (2007): 469.
}

B. Keluhan Daud Diungkapkan (ay. 2-3)

a. Keluhan Daud Kepada Tuhan (ay. 2)

b. Keluhan Daud Kepada Dirinya Sendiri (ay. 3a)

c. Keluhan Daud Kepada Musuhmusuhnya (ay. 3b)

C. Permohonan Daud Disampaikan (ay. 4-5)

a. Permohonan untuk Dipandang (ay. 4a)

b. Permohonan untuk Dijawaban (ay. 4a)

c. Permohonan untuk Diterangi (ay. 4b)

d. Tujuan permohonan: agar tidak mati (ay. 4b)

e. Tujuan permohonan: agar musuh tidak menguasainya (ay. 5a)

f. Tujuan permohonan: agar musuh tidak bersorak-sorak (ay. 5b)

D. Keyakinan Daud Dinyatakan (ay. 6)

a. Keyakinan Ditegaskan (ay. 6a)

b. Hatiku Bersukacita (v. 6b)

c. Aku akan Bernyanyi (v. 6e)

d. Dasar Bagi Pujian (v. 6d)

\section{Pembukaan (ay.1)}

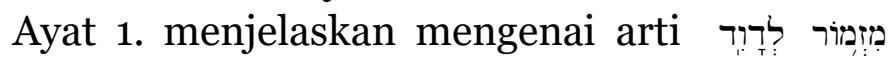
mizmōwr lod $\underline{d} \bar{a} w i \underline{d}$. Ross menegaskan bahwa

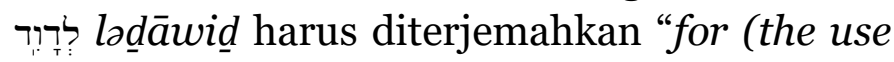
of) David" dan bahkan jika itu diterjemahkan "oleh Daud," masih ada dua masalah utama dengan kepengarangan Daud atas Mazmur ini. Pertama, beberapa Mazmur dianggap berasal dari Daud yang nampaknya digunakan dalam Bait Allah, padahal Daud meninggal sebelum Bait Allah ini dibangun. Kedua, ada perkembangan dalam bahasa Ibrani di seluruh corpus Daud, menyarankan beberapa yang ditulis lebih awal daripada yang lain. ${ }^{29}$

Di sisi lain, ada beberapa pakar yang menentang kepengarangan Daud. Meskipun ia mungkin akan menyangkal kepenulisan Daud, Gentry tetap memberikan argumen persuasif bahwa לִדיוֹר ladâwid harus dipahami sebagai menunjukkan kepenulisan Daud. ${ }^{30}$ Setelah

\footnotetext{
${ }^{29}$ Allen P Ross, A Commentary on the Psalms (Grand Rapids: Kregel Academic, 2011), 112.

${ }^{30}$ Peter J Gentry, “A Preliminary Evaluation and Critique of Prosopological Exegesis," The Southern Baptist Journal of Theology 23, no. 2 (2019): 111, 115.
} 
Gesenius dan Eissfeldt, Kraus secara benar menegaskan bahwa ? lo harus diambil sebagai sebuah ? lo auctoris (yang menunjukkan penulis). ${ }^{31}$

A. A Anderson dan Craigie mengakui, ada tradisi kuno dan kuat yang mengidentifikasi Daud sebagai komposer, musisi, dan penyanyi, ${ }^{32}$ Selain tiga belas superscription mazmur yang menghubungkan peristiwa tertentu dalam kehidupan Daud untuk komposisi mazmur yang bersangkutan, tradisi Daud ini lebih lanjut dibuktikan dalam bagianbagian seperti 1 Samuel 16:17-23; 18:10; 2 Samuel 1:17 -27; 3:33-34; 6:5; 22; 23:1-7; 1 Tawarikh 13:8; 15:3-28; 16:4-43; 23:15; 25; Ezra.3: 10; Nehemia 12:24; dan Amos 6:5. Oleh karena itu masuk akal untuk menempatkan penulis Mazmur 13 adalah Daud sendiri.

\section{Keluhan Daud diungkapkan}

\section{(ay. 2-3)}

Kedua ayat ini merupakan keluhan Daud dengan tiga sasaran utama, yakni; pertama, Daud mengeluh kepada Tuhan; kedua, Daud mengeluh kepada dirinya sendiri; ketiga, Daud mengeluh kepada musuh-musuhnya. Masingmasing keluhan tersebut disampaikan dengan menggunakan kata ganti interogatif (kalimat

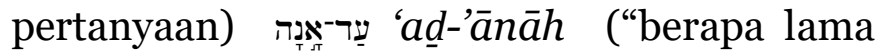
lagi?”) dari akar kata אָ ān. Menurut Delitzsch, "pertanyaan rumit ini: sampai kapan, berapa lama ... terus-menerus adalah sebuah ekspresi dari kondisi jiwa rumit, dan jika melihat penggunaan kalimat interogatif tersebut dalam Mazmur (seperti yang terdapat juga dalani Mzm. 74: 10; Mzm. 79: 5; Mzm. 89: 47), keluhan ini mengacu pada ekspresi perasaan kesedihan karena ada di bawah murka Allah.”33 Keluhan ini disampaikan saat pemazmur ada

\footnotetext{
${ }^{31}$ Kraus, Psalms 1-59: A Continental Commentary, 22-23.

${ }^{32}$ Anderson, The Book of Psalms V. 1 Introduction and

Psalms 1-72, 44.

${ }^{33}$ Delitzsch, Biblical Commentary on the Psalms (Vol. 3), 200.

${ }^{34}$ William L Holladay, A Concise Hebrew and Aramaic Lexicon of the Old Testament (Grand Rapids: William
}

“di tengah-tengah" masalahnya. Tampaknya, ia telah menanggung masalah ini selama dia bisa, namun masalah tersebut belum berakhir. Kita mungkin dapat menganggap bahwa ia telah sabar dan tanpa mengeluh, bahwa ia telah diuji menunggu dengan sabar untuk pembebasan, namun sekarang ia mulai putus asa. Ia merasa bahwa masalahnya tidak akan pernah berakhir. Dia melihat tidak ada prospek pembebasan, tidak ada tanda-tanda atau bukti bahwa Allah akan campur tangan, seolah-olah ia benarbenar ditinggalkan dan itu bersifat selamanya. Jadi, pengulangan keluhan ini sebanyak tiga kali untuk menunjukkan; (1) ekspresi keputusasaan pemazmur yang menderita berkepanjangan, yang mungkin telah berlangsung untuk beberapa waktu, dan (2) menjadi bukti bahwa ia sungguh mengharapkan pembebasan dari Allah dapat segera terwujud.

\section{Keluhan Daud Kepada Tuhan} (ay. 2)

Mazmur ratapan atau keluhan umumnya diarahkan kepada Tuhan. Hal tersebut ditunjukkan dalam bagian awal Mazmur ini, di mana keluhan Daud yang pertama diarahkan kepada Tuhan. Pemazmur membahas Tuhan secara langsung dalam seruan יהוזה Yahweh. Daud mengira bahwa YHWH telah

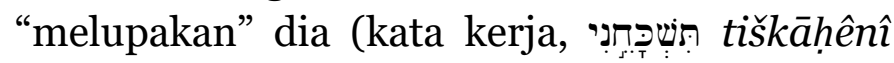
dari akar kata שָָׁ shakah yang artinya "lupa/melupakan atau mengabaikan"). ${ }^{34}$ Kata Ibrani yang dipakai disini mengandung tindakan YHWH sebagai subjek yang "melupakan" Daud dalam pengertian rohani. ${ }^{35}$ Tampaknya pemazmur merasa bahwa YHWH secara pasif duduk sementara ia menderita, itulah sebabnya ia mengunakan kiasan dan YHWH “melupakan.” Menurut A. A. Anderson ini merupakan "sikap acuh tak acuh yang

B. Eerdman's, 2000), 369. Victor P Asherah Hamilton, In Theological Wordbook of the Old Testament, Ed. R. Laird Harris, Vol. 1, 80-82 (Chicago: Moody Press, 1980),412.

${ }^{35}$ Ludwig Koehler et al., dalam "rote" The Hebrew and Aramaic Lexicon of the Old Testament (Leiden: EJ Brill, 1994),380. 
disengaja pada pihak Tuhan untuk beberapa alasan yang tidak ditentukan," yang menyiratkan bahwa pemazmur sedang tidak disukai Allah. ${ }^{36}$

Namun, absennya kemurahan Allah tidak berarti Ia tidak mengasihani, misalnya, dalam Mazmur 22, 42, 44, 74, 77, dan 88, dengan jelas mengindikasikan ketidakkasihan Allah, yang Ia ungkapkan baik melalui sikap pasif dalam menghadapi penderitaan pemazmur atau melalui hukuman permusuhan yang aktif. ${ }^{37}$ Namun dalam Mazmur 13 tidak ada pengakuan akan kesalahan, yang ada adalah permohonan pemazmur muncul dari rasa kecemasan yang mendalam, bukan penyesalan. ${ }^{38}$

Situasi tertekan dari pemazmur ini nampaknya sudah berlangsung cukup lama. Hal ini terbukti

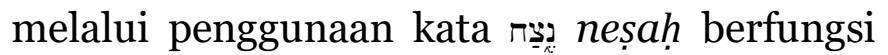

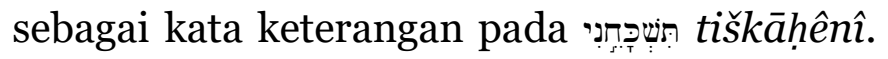

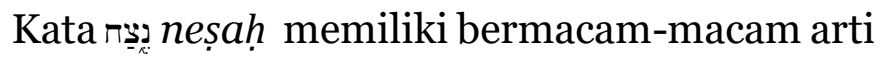
("kekuatan, kemenangan, abadi, tak hentihentinya, atau terus-menerus"), ${ }^{39}$ namun dalam konteks ini kata נֵֵِِ neșah lebih baik diterjemahkan sebagai "terus-menerus" yang menekankan pada "durasi waktu yang panjang atau tak ada habis-habisnya." 40 Berbeda dengan Anderson yang lebih menyukai terjemahan נֵِِ neșah sebagai "sepenuhnya" 41 namun pilihan terjemahan ini memiliki dukungan leksikal yang kecil. Jadi, penekanan keluhan pemazmur ini adalah pada panjangnya penderitaan, bukan pada besarnya kepasifan Allah. Dengan demikian, klausul tersebut sangat benar diterjemahkan, "Berapa lama, ya TUHAN, Engkau terus-menerus melupakanku?"

Bagian kedua dari keluhan terhadap Tuhan adalah karena Ia "menyembunyikan wajah"

\footnotetext{
${ }^{36}$ Anderson, The Book of Psalms V. 1 Introduction and Psalms 1-72, 128.

${ }^{37}$ Broyles, The Conflict of Faith and Experience in the Psalms: A Form-Critical and Theological Study, 184.

${ }^{38}$ Craigie and Marvin, Word Biblical Commentary, Psalm 1-50, Volume 19, 142.

${ }^{39}$ Robert L Harris, Theological Wordbook of the Old Testament (Chicago: Moody Press, 1981), 395.
}

terhadap pemazmur (ay. 2b). Kalimat ini merupakan sintetis yang sejajar dengan yang pertama, yang pada dasarnya pemazmur

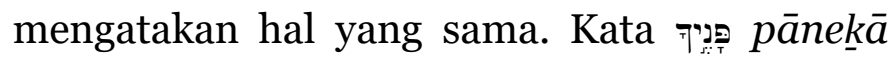
(lit., "wajah-Mu”) adalah bahasa figuratif yang mengacu pada kehadiran Tuhan. ${ }^{42}$ Jadi, keluhan ini mengacu pada perasaan seolah-olah ditinggalkan tanpa kehadiran atau intervensi Tuhan.

\section{Keluhan Daud Kepada Dirinya Sendiri (ay. 3a)}

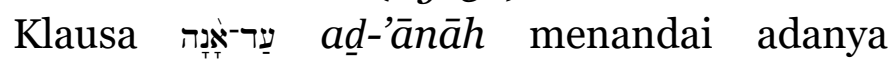
transisi fokus dari Allah kepada pemazmur. Dia bertanya berapa lama dia harus "menaruh" (אָשָית 'à.šît qal imperfek) kekuatiran di dalam jiwanya. Sebuah petunjuk mengenai arti dari

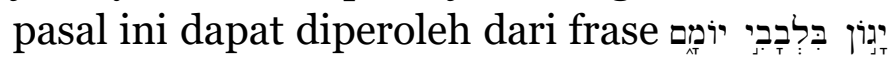
yā̄ōôn bilbābồ yōwmām, yang merupakan objek langsung kedua yang melekat pada kata

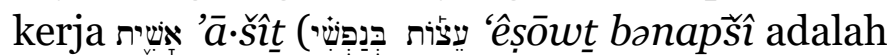
objek langsung pertama). Tampaknya lebih baik mengambil objek langsung kedua sebagai ironisnya berlawanan dengan yang pertama.

Pemazmur mengeluh terhadap dirinya sendiri karena ada "kekuatiran dalam dirinya." Dengan kata lain, "jiwanya" sedang mengalami tekanan. Jika dipertimbangkan dari aspek psikologis

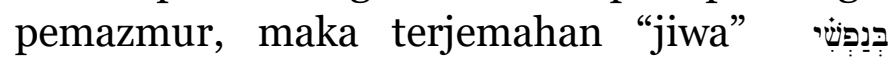
bənapšî dari akar kata נפּש nephesh lebih baik dari pada terjemahan yang dipilih LAI "diriku." Jadi seruan ini keluar dan kedalaman jiwanya yang merupakan tempat berdiamnya pikiran

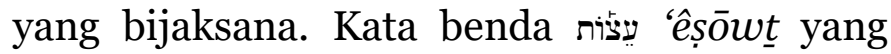
diterjemahkan LAI "kekuatiran" juga masih diperdebatkan. KJV dan NAS memilih "counsel, " sedangkan NET memilih "worry. Argumentasinya bisa dipecahkan dengan

\footnotetext{
${ }^{40}$ Koehler et al., The Hebrew and Aramaic Lexicon of the Old Testament, 338.

${ }^{41}$ Anderson, The Book of Psalms V. 1 Introduction and Psalms 1-72, 128.

${ }^{42}$ Francis Brown, Samuel Rolles Driver, and Charles Augustus Briggs, A Hebrew and English Lexicon of the Old Testament: With an Appendix Containing the Biblical Aramaic (Peabody: Hendrickson Publishers, 2007), 816.
} 
melihat penggunaan kata tersebut dalam Alkitab. Bentuk jamak kata ini hanya muncul tiga kali dalam Perjanjian Lama (di sini dan di Kitab Ul. 32:28 dan Yesaya 25:1); dalam setiap contoh itu bukan merupakan istilah netral melainkan istilah yang menunjukkan moralitas positif yang membawa gagasan "nasihat yang bijaksana" atau "kebijaksanaan." Jika ini benar, maka pemazmur menarik perhatian kepada ironi dan secara efektif meminta kepada Tuhan, "Mengapa aku mengalami kesedihan di hatiku ketika aku benar dalam jiwaku?"43

Kenyataan kedua dan keluhan pemazmur atas situasi berat yang menimpa dirinya diungkapkan melalui kata benda גיגר "bersedih" atau "penderitaan yang mendalam." Sebuah ungkapan yang mengandung makna utama terjadinya mengganggu mental akibat penderitaan atau menekankan kesedihan mental dalam penderitaan.

Situasi jiwa yang berat seperti ini dialami pemazmur "sepanjang hari." Penggunaan yang tepat dari istilah יָּר diperdebatkan. Beberapa komentator bersikeras bahwa seharusnya istilah ini diterjemahkan "setiap hari" bukannya "sepanjang hari." Perbedaannya terletak nuansa: "Setiap hari" menekankan durasi penderitaan yang berkepanjangan, sementara "sepanjang hari" menekankan pada the allconsuming totality of the suffering. Dengan kata lain, apakah kesedihan dalam hati pemazmur terjadi "setiap hari" atau "sepanjang hari”? Alexander dan Hengstenberg menarik Yehezkiel 30:16 untuk berdebat mengenai kata "setiap hari." 4

Dalam menyetujui pandangan ini, Francis Brown, Driver dan Briggs mengutip Mazmur

\footnotetext{
${ }^{43}$ Stephen L Dolson-Andrew, "An Exegesis of Psalm 13," CTS Journal 4 (2004): 61.

${ }^{44}$ Joseph Addison Alexander, The Psalms Translated and Explained (Grand Rapids: Baker Academic, 1975), 98.
}

13:3 sebagai contoh puitis (yaitu, non-literal) menggunakan יוֹ yôwmām dengan pengertian sebagai "terus-menerus." ${ }^{45}$ Di sisi lain, Delitzsch memilih "sepanjang hari" dan tidak setuju dengan "setiap hari," alasannya bahwa Yehezkiel 30:16 tidak meyakinkan. Ia berpikir bahwa לִילָ: lāyolāh tersirat dalam ay 3a, yang mengarah ke interpretasi terhadap penyusunan rencana-rencana yang masing-masingnya bernilai dan kemudian pada siang hari, atau sepanjang hari yang dilalui, ketika ia melihat kesusahan dengan mata terbuka, ia menjadi sedih di dalam hatinya, karena perasaan seperti malam hari meninggalkannya dan sebagai gantinya kondisinya langsung tak berdaya dan putus asa. ${ }^{46}$

Hal ini menunjukkan pemikiran Delitzsch yang kreatif, tetapi ia tidak dapat membuktikan hal itu dari konteks ini, dan dasar pikiran yang mendukung penafsirannya tidak kuat. Ia juga tidak menyatakan mengapa Yehezkiel 30:16 tidak persuasif sebagai bukti untuk pandangan alternatif.

\section{Keluhan Daud Kepada Musuh-musuhnya} (ay. 3b)

Klausa yang memberi bukti adanya transisi fokus dari pemazmur kepada musuh-musuhnya

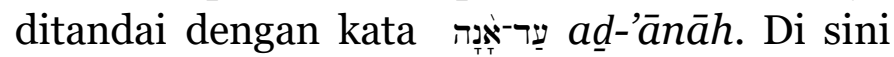
ditunjukkan penyebab kesedihan pemazmur dan perasaannya bahwa Tuhan seolah-olah telah melupakan dia: musuhnya sedang meninggikan diri (אָָָ 'ānāh) atasnya. Apakah yang dimaksud pemazmur sebagai "musuh" di sini? Apakah itu mengacu kepada "seorang musuh" atau "sesuatu hal" (misalnya penyakit)?

Berdasarkan penggunaan kata אָָָ ānāh di tempat lain (Mik. 7:8 dan Ul. 24:7), "musuh" yang dimaksudkan di sini mengacu kepada

\footnotetext{
${ }^{45}$ Francis Brown, Driver, Briggs, $A$ Hebrew and English Lexicon of the Old Testament: With an Appendix Containing the Biblical Aramaic , 401.

46 Funlola Olojede, ““...What of the Night?’ Theology of Night in the Book of Job and the Psalter," Old Testament Essays 28, no. 3 (2015): 731-732. Delitzsch, Biblical Commentary on the Psalms (Vol. 3), 200.
} 
"musuh" dalam pengertian "seorang musuh" bukan musuh dalam pengertian "penyakit." Menurut Dolson-Andrew, kemungkinan pemazmur menghadapi seorang musuh pribadi (Saul?) yang keras kepala dan berhasil menimbulkan kemarahannya sampai ke titik kematian. ${ }^{47}$ Interpretasi terbaik menggabungkan pandangan Staton dan Craigie, dimana musuh tunggal adalah salah satu individu yang memegang kendali utama dan kelompok umum musuh yang selaras terhadap pemazmur.

\section{Permohonan Daud disampaikan}

\section{(ay. 4-5)}

Setelah Daud mengekspresikan keputusasaannya terhadap musuh (Saul?) yang menyedihkan hatinya melalui ratapan atau keluhan, sekarang ia mengajukan tiga permohonan kepada Allah dengan tiga konsekuensi yang mengikutinya.

\section{Permohonan Pertama: Lihatlah aku (ay. 4a)}

Permohonan pertama kepada Tuhan ditandai

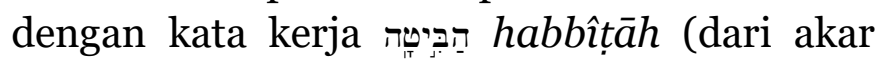
kata nבט nabat dengan penggunaan pangkal hiphil yang berarti "lihatlah" atau "perhatikanlah." Menurut Ludwig Koehler dan Walter Baumgartner, kata ini mengandung pengertian bahwa pemazmur memohon kepada Tuhan agar ia mendapatkan kemurahan atau ganjaran kelepasan. ${ }^{48}$ Alih-alih Tuhan menyembunyikan wajah-Nya dari pada dia (ay. 2), secara harfiah pemazmur meminta Tuhan untuk "lihat aku."

\section{Permohonan kedua: Jawablah aku (ay. 4a)}

Kata ganti objek langsung dengan akhiran

\footnotetext{
${ }^{47}$ Mitchell J Dahood, Psalm I:1-50 (Garden City:

Doubleday, 1966), 105.

${ }^{48}$ Koehler et al., The Hebrew and Aramaic Lexicon of the Old Testament, 354.

${ }^{49}$ Nico Daams, "Translating YHWH Elohim," The Bible Translator 62, no. 537; Hebrew Bible and its Versions, 6 (2011): 229-231.
}

("aku") dari kata kerja imperatif kedua

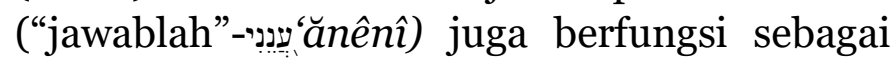
objek langsung dari kata kerja "lihatlah" הַחקיטוּה habbîtâh, sehingga dapat diterjemahkan "lihatlah aku" dan "jawablah aku." "TUHAN" adalah bentuk seruan (vokatif) sebagai "Allahku" (אל 'ělōhāy), yang berfungsi sebagai keterangan tambahan (aposisi) kepada kata יהוזה: (TUHAN). ${ }^{49}$ Melalui penyebutan ini, Tuhan tidak menjauhkan diri-Nya, kemahakuasaan Ilahi belum dipasifkan bagi pemazmur, Tuhan ini adalah "Allahku." Ini merupakan sebuah seruan yang halus kepada Tuhan sebagai "Ilah pelindung” dalam konteks kultis dari Timur Dekat Kuno, dimana juga dikatakan sebagai pencipta, penguasa, dan pemelihara alam semesta. ${ }^{50}$

\section{Permohonan ketiga: Terangilah mataku} (ay. 4b)

Permohonan ketiga disampaikan dengan

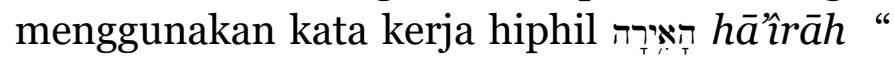
terangilah." Hal yang diminta pemazmur untuk

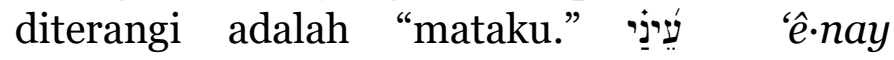
sepanjang Perjanjian Lama, Allah dikatakan sebagai yang menerangi mata orang: Makna yang mendasari kalimat ini tampaknya memberikan hidup, karena sebuah doa bagi terang Allah untuk diberikan kepada mata benar-benar suatu permohonan untuk menghindari kematian (Mzm. 13:3 [4]). Dalam pengertian ini mengingat kembali ekspresi yang sama pada "terang kehidupan." Menerima terang dengan cara ini tergantung pada wajah Allah sedang berpaling ke arah seseorang. Masalah dalam Mazmur 13:3 [4] adalah wajah Allah tersembunyi (ay.1 [2]), yakni, terang wajah Allah tidak bersinar pada orang yang
${ }^{50}$ Shon Hopkin, "My God, My God, Why Hast Thou Forsaken Me?" Psalm 22 and the Mission of Christ," Byu Studies Quarterly 52, no. 4 (2013): 151. Eko Wahyu Suryaningsih, "Doktrin Tritunggal Kebenaran Alkitabiah," PASCA : Jurnal Teologi dan Pendidikan Agama Kristen 15, no. 1 (2019): 20, https://doi.org/10.46494/psc.v15i1.64. 
berdoa. ${ }^{51}$ Ini adalah pandangan mayoritas, dan itu sangat baik disimpulkan oleh Delitzsch, untuk menerangi mata yang redup dengan kesedihan dan siap untuk beristirahat, adalah perkataan yang sama artinya untuk memberikan kehidupan baru (Ezra 9:8), yang tercermin dalam terang mata yang jernih dan segar . ${ }^{52}$ Namun, pandangan H. Schmidt yang berpendapat bahwa kekhawatiran utama pemazmur adalah karena penyakit mata yang menimpa dirinya sudah menyimpang jauh sekali, karena terlalu banyak membaca ekspresi

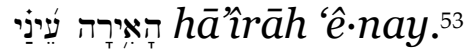

Tujuan permohonan: agar tidak mati (ay. 4b) Pemazmur sekarang mendaftarkan tiga hal yang mungkin terjadi jika Tuhan gagal untuk campur tangan. Dua dan tiga klausa tersebut secara eksplisit dimulai dengan "jangan" (פק pen), dan klausa ketiga secara implicit dimulai dengan "jangan." Pada klausa pertama, pemazmur berbicara tentang "sleep the sleep of death." Secara harfiah, frasa ini dibaca "jangan aku tertidur mati." Namun begitu, ini adalah sebuah contoh utama dari skema etymologicum, di mana Tiș hammāwet

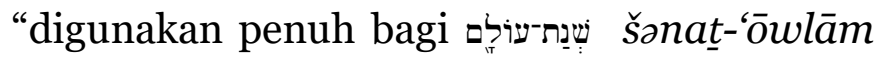
(band. Yeh 51:39).54 Tentu saja, ayat-ayat seperti Ayub 3:13, 14:12, dan Mazmur 76:5 [6] hanya beberapa dan banyak bagian PL di mana fungsi tidur sebagai metafora untuk kematian.

\section{Tujuan permohonan:} agar musuh tidak menguasainya

$$
\text { (ay. 5a) }
$$

Beberapa komentator mengambil bentuk

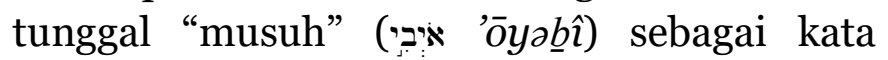
benda kolektif yang mengacu pada sekelompok musuh, terutama karena bentuk jamak "lawanlawanku" (צִ șāray) yang mengikuti

\footnotetext{
${ }^{51}$ Douglas W Stott et al., Theological Dictionary of the Old Testament (Grand Rapids: Wm. B. Eerdmans Publishing, 2003), 158.

52 Ernst Hengstenberg, Commentary on the Psalms, (Bellingham: Logos Research System, 2010), 200-201.

${ }^{53}$ Kraus, Psalms 1-59: A Continental Commentary, 213.

${ }^{54}$ Wilhelm Gesenius, Emil Kautzsch, and Arthur Ernest Cowley, Gesenius' Hebrew Grammar (Oxford: Courier
}

paralelisme. Di sisi lain, Staton, berpikir bahwa penulis asli mungkin telah memiliki seorang individu yang sebenarnya dalam pikiran. ${ }^{55}$ Sementara di pihak lain ada yang melihat musuh tunggal tersebut sebagai kematian itu sendiri. Craigie percaya bahwa perbedaan dalam jumlah ini disengaja: "Musuh tunggal ini tidak diragukan lagi adalah personifikasi dan kematian, sedangkan musuh jamak adalah musuh pemazmur pada umumnya." ${ }^{56}$ Dahood, sementara setuju dengan Craigie bahwa musuh tunggal itu adalah kematian itu sendiri, namun tidak setuju pada Craigie atas perbedaan dalam jumlah: "Plurale majestatis [ִּ șāray] yang merupakan nama lain untuk musuh pemazmur, Mot" - yaitu, kematian - "the adversary par excellence. ${ }{ }_{57}$ Menurut Dolson-Andrew "Mungkin interpretasi terbaik adalah menggabungkan pandangan Staton dan Craigie ini: musuh tunggal adalah salah satu individu [Saul?] yang memegang kendali utama dari kelompok umum musuh yang bersekutu melawan pemazmur." 58

\section{Tujuan permohonan:}

agar musuh tidak bersorak-sorai (ay. 5b)

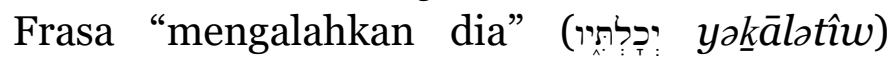
adalah terjemahan yang lebih tepat daripada "menang melawan dia," karena ini adalah kata ganti obyek langsung akusatif daripada preposisi terpisah dengan akhiran kata ganti, yang akan berarti ide datif. ${ }^{59}$ Seseorang mungkin mengharapkan penggunaan jauh lebih umum is lu dengan 13:5 tampaknya menjadi satu kejadian dalam Perjanjian Lama dari bentuk kata kerja ini, tapi Dahood telah mengajukan bukti dari Ugaritic Textbook yang menunjukkan pembacaan

Corporation, 2006), 367.

${ }^{55}$ Staton Jr, "How Long, O Yahweh?' The Complaint

Prayer Of Psalm 13," 62.

${ }^{56}$ Craigie and Marvin, Word Biblical Commentary,

Psalm 1-50, Volume 19, 142.

${ }^{57}$ Dahood, Psalm I:1-50, 105.

${ }^{58}$ Dolson-Andrew, "An Exegesis of Psalm 13."

${ }^{59}$ Hengstenberg, Commentary on the Psalms, 201. 
Masoretic Text. ${ }^{60}$ Klausa kedua dari kalimat ini

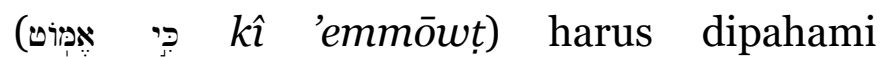
mengandung awalan pen yang tersirat, yang menandai klausa sebagai hasil negatif ketiga dalam klausa permohonan. Seperti Genesius, Kautzsch dan Cowley katakan, mengutip Mazmur 13:5 sebagai salah satu contoh, "negatif kadang-kadang pengaruhnya meluas dari yang pertama sampai kepada kalimat paralel negatif kedua (yang mungkin atau yang tidak mungkin memiliki $\left(? W^{e}\right) \ldots . .{ }^{61}$

Delitzsch mungkin benar bahwa kata כִּ אִ $k \hat{\imath}$ 'emmōwt harus diambil sebagai klausa temporal dan bukan sebagai sebuah penyebab klausa. Ini dikarenakan כִ kî diikuti oleh bentuk

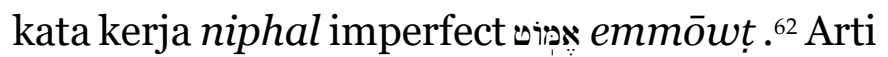
אֶ: emmōwt ("dijatuhkan” atau “digoyahkan”) mungkin ungkapan halus untuk pengertian mati, tetapi biasanya "itu adalah gambaran dari kemalangan pada umumnya.”63

\section{Keyakinan Daud dinyatakan (ay.6)}

Untuk menandai dengan tegas transisi dari permohonan kepada ekspresi iman, pemazmur memulai ayat ini dengan וַאִ wa wănî, Westermann mengidentifikasi ini sebagai waw berlawanan (adversative) dan ia mengutip dengan sering penggunaannya dalam mazmur ratapan individu untuk menandai transisi ke pengakuan iman. ${ }^{64}$ Meskipun ? waw yang secara gramatikal terkait dengan ayat 5 , hampir tidak ada keraguan bahwa dari perspektif kritik

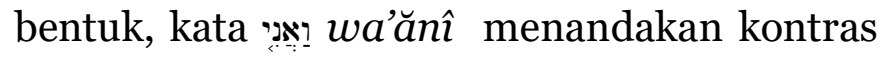
yang cukup jelas dan adanya kemajuan dalam suasana hati untuk mendekat kepada Allah. ${ }^{65}$

\footnotetext{
${ }^{60}$ Dahood, Psalm I:1-50, 78.

${ }^{61}$ Gesenius, Kautzsch, and Cowley, Gesenius' Hebrew Grammar, 143.

${ }^{62}$ Delitzsch, Biblical Commentary on the Psalms (Vol. 3), 201.

${ }^{63}$ Anderson, The Book of Psalms V. 1 Introduction and Psalms 1-72, 130.

${ }^{64}$ Westerman, Praise and Lament in the Psalms, 70-75.

${ }^{65}$ Samgar Setia Budhi, "Eksegesis Mazmur 73:

Pergumulan Orang Benar Tentang Kemakmuran Orang
}

\section{Keyakinan Ditegaskan}

(ay. 6a)

Pemazmur tidak menunggu Tuhan untuk membuktikan diri-Nya. Sekarang, keputusasaan digantikan dengan iman yang segar. Penegasan bahwa pemazmur sudah beriman dapat dilihat dan penggunaan bentuk

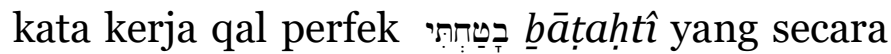
harfiah dapat diterjemahkan "aku sudah memiliki iman." Dan dasar ungkapan keyakinan

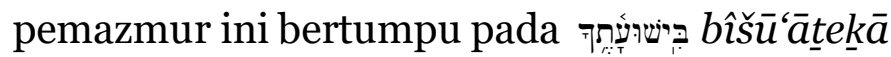
"kasih karunia" (dari akar kata חֶ: [hesed]]) Allah. ${ }^{66}$

Selama berabad-abad kata hesed diterjemahkan dengan kata-kata seperti kemurahan, kebaikan, kasih setia. Septuaginta biasanya menggunakan eleos "belas kasihan," dan Latin misericordia. Targum dan Syria sering menggunakan bahasa serumpun dari tob. Akar kata ini tidak ditemukan dalam bahasa Akkadia atau Ugarit. Leksikon melalui BDB dan GB (yang mengatakan Liebe, Gunst, Gnade, cinta kebaikan, kasih karunia) adalah sama. ${ }^{67}$

Kata hesed memiliki pengertian yang sangat penting dalam Perjanjian Lama. Kata ini menunjukkan kasih dan kesetiaan yang ditunjukkan oleh Allah kepada umat perjanjianNya, yaitu kepada para nenek moyang Israel, keturunan mereka, dan anak-anak mereka. Kata ini digunakan pertama kali dalam Kejadian 24:12 dan tampaknya sedikit sekali, itu pun jika ada, aplikasi dalam PL kepada siapapun di luar lingkaran perjanjian. ${ }^{68}$ Sedangkan hesed biasanya merefleksikan "sikap karakter Tuhan" yaitu, sikap yang bertentangan dengan tindakan - yang umumnya memiliki motif berbeda dalam

Fasik," HUPERETES: Jurnal Teologi dan Pendidikan Kristen 1, no. 1 (December 14, 2019): 5, http://sttkalimantan.ac.id/ejournal/index.php/huperetes/article/view/1.

${ }^{66}$ Gustav R Rame, "Menyembah Tuhan: Suatu Studi Exegetis Mazmur 100," Missio Ecclesiae 4, no. 2 (2015): 111-112.

${ }^{67}$ Harris, Theological Wordbook of the Old Testament, 134. ${ }^{68}$ Anderson, The Book of Psalms V. 1 Introduction and Psalms 1-72, 134. 
Mazmur, dan khususnya (jika tidak secara eksklusif) dalam ratapan: Allah menunjukkan kesetiaan-Nya kepada umat perjanjian-Nya dengan cara dari-Nya hesed, yakni "menyelamatkan manusia dari bencana atau penindas-penindas." ${ }^{69}$ Selain itu, hesed akan memiliki gema khusus bagi Daud, kepada siapa Tuhan berjanji bahwa hesed-Nya "tidak akan pernah hilang" (2 Sam. 7:15).

\section{Hatiku Bersukacita (ay. 6b)}

Dalam klausa kedua, hati pemazmur, yang saat itu penuh dengan kesedihan (ayat 3), tetapi di masa depan "hatiku bersukacita" (ליר libbî) di dalam Tuhan penyelamat atau pembebas. Sedangkan musuh-musuhnya dapat bersukacita di dalam ayat 5 , ia mengungkapkan keyakinan bahwa dia akhirnya akan menjadi salah satu sukacita. Kata 쌈 yāgêl mungkin harus diambil sebagai suatu jussive dengan implikasi masa depan (bukan suatu jussive dengan konotasi imperatif atau voluntative), karena keselamatan yang bersangkutan belum terjadi.

Pada kalimat berikutnya, kata $\bar{g} \bar{g} \bar{a} m a l$ ada dalam bentuk kala perfek dalam klausa dependen, dan A. A Anderson dengan benar mengidentifikasi bentuk kata itu sebagai sebuah kepastian yang sempurna, yaitu pemazmur menggunakan kala perfek untuk mengekspresikan keyakinan imannya bahwa Tuhan pasti akan campur tangan dalam masalahnya. ${ }^{70}$

\section{Aku akan Bernyanyi} (ay. 6c)

Bentuk kata kerjanya adalah cohortative, menunjukkan tekad pemazmur (atau sumpah) untuk memuji Tuhan saat pembebasan tiba.

\footnotetext{
${ }^{69}$ Brown, Driver, and Briggs, A Hebrew and English Lexicon of the Old Testament: With an Appendix Containing the Biblical Aramaic, 339.

${ }^{70}$ Anderson, The Book of Psalms V. 1 Introduction and Psalms 1-72, 130.

${ }^{71}$ Alexander, The Psalms Translated and Explained, 100.
}

Iman telah menang. Ia bisa berharap dengan keyakinan. Tapi kerendahan hati mengubah resolusi untuk mengucap syukur dalam doa. Dengan demikian, tampaknya ada sebuah kemajuan lisan yang menarik dari perfect ("Aku telah percaya) kepada jussive future ("Hatiku akan bersukacita") kepada cohortative voluntative ("Biarkan aku bernyanyi"), terakhir ke perfect ("Ia telah berbuat baik" dalam arti bahwa "it is as good as done." Dimana ada nada yang sama tetapi tidak identik, melihat sebuah "gradasi indah di klausul ayat ini," dan fakta menyatakan ("percaya") kepada keinginan yang dinyatakan ("biarkan aku bersukacita") kepada tujuan yang pasti ("Saya akan bernyanyi”). ${ }^{71}$

\section{Dasar bagi pujian \\ (ay. 6d)}

Dasar pujian Daud kepada Tuhan adalah "Karena Ia telah berbuat baik kepadaku." Kala

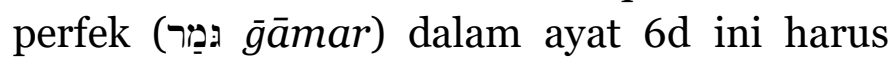
dipahami demikian: perayaan mengikuti fakta yang mengilhami dia untuk bertekad menyanyi bagi Tuhan. ${ }^{72}$ Menurut Keil dan Delitzsch frasa

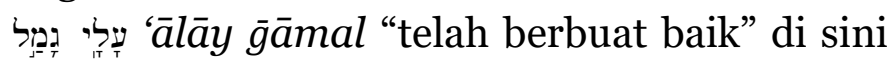
sama seperti yang terdapat dalam Mazmur 116:7 dan Mazmur 119:17, yang secara radikal

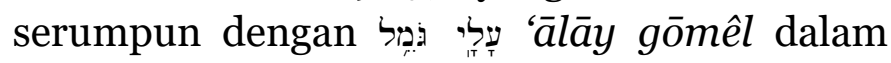
Mazmur 57:3.73 Dalam badai yang bergejolak dalam jiwa pemohon, sekarang semuanya telah menjadi tenang, yang mana kedamaian memerintah di kedalaman hatinya. Penggunaan kala perfek di sini mengandung arti bahwa "pemazmur yakin bahwa doanya telah didengar, ia memutuskan untuk bersukacita dan bernyanyi kepada Tuhan yang memberinya keselamatan dan berbuat baik kepadanya. (Ini adalah yang pertama dari beberapa lusin referensi dalam Mazmur bagi Allah yang baik). Dia sepenuhnya mengantisipasi akhir penantiannya yang panjang." ${ }^{74}$

\footnotetext{
${ }^{72}$ Delitzsch, Biblical Commentary on the Psalms (Vol. 3), 201.

${ }^{73}$ Davida H. Charney, "Performativity and Persuasion in the Hebrew Book of Psalms: A Rhetorical Analysis of Psalms 116 and 22," Rhetoric Society Quarterly 40, no. 3 (2010): 259.

${ }^{74}$ Ross, A Commentary on the Psalms, 802.
} 


\section{Tujuan dan Nilai}

Tujuan langsung dan pribadi dan Mazmur 13 adalah untuk mencari pembebasan Tuhan dari kesusahan berat dan ketidakberdayaannya menghadapi tekanan itu secara terus-menerus. Kendati pemazmur jelas tak berdaya, namun dia tahu bahwa ia dapat mempercayai atau mengandalkan Tuhan untuk membebaskannya. Dasar dan keyakinannya adalah perjanjian hesed ("kasih setia") Allah (ini juga hampir tercatat kepada semua subgenre ratapan). ${ }^{75}$

Tujuan akhir pemazmur bahwa ia juga ingin menolong orang lain. Dengan demikian pemazmur menyelesaikan tujuannya sebagai berikut: Pertama, dengan mengungkapkan penderitaannya sendiri, pemazmur mendorong orang lain yang menderita untuk mengetahui bahwa mereka tidak sendirian dalam penderitaannya mereka dapat mengidentifikasi diri dengannya. Kedua, untuk memberikan model kekuatan moral dan spiritual dalam menghadapi kesulitan hidup yang berat. Ketiga, untuk mengajar orang lain bagaimana berdoa di saat krisis. ${ }^{76}$ Keempat, untuk menunjukkan bahwa Tuhan adalah tempat perlindungannya satu-satunya, penyelamat yang kuat, dan perjanjian kasih setia-Nya yang dapat diandalkan selama-lamanya.

Dengan demikian pusat perhatian bukanlah perubahan yang bersifat keberuntungan atau kebetulan, tetapi penyelamatan Allah sendiri, yang menyelamatkan dari dunia kematian, menerangi mata (ayat 3), dan melakukan halhal yang baik (ay $5 \mathrm{~b}$ ).77

Seperti yang disebutkan di atas, adanya suatu

\footnotetext{
${ }^{75}$ Logan C. Jones, "The Psalms of Lament and the Transformation of Sorrow.," The journal of pastoral care \& counseling : JPCC 61, no. 1-2 (2007): 47-58.

${ }^{76}$ Mays, Psalms, 80.

${ }^{77}$ Kraus, Psalms 1-59: A Continental Commentary, 217.

${ }^{78}$ L P Mare, "Psalm 22 : To Pray like Jesus Prayed 1," Old Testament Essays 17, no. 3 (2004): 444.

${ }^{79}$ Eko Mulya Tua, "Respon Daud Dalam Menghadapi Pergumulan: Studi Terhadap Kitab Mazmur 3:1-9,"
}

repetisi dalam nada-nadanya yang mencolok, dan gerakan pertama mengenai penderitaan kemudian terakhir bergerak kepada ketenangan. Ketika Kristus menderita di kayu salib, Ia mengutip Mazmur 22: "Allah-Ku, Allah-Ku, mengapa Engkau meninggalkan Aku? (Mat. 27:46, NKJV), di situ adanya persamaan antara Mazmur 13 dan 22.78 Belakangan mazmur ini juga merupakan ratapan pribadi, dan juga mengikuti bentuk ratapan lainnya (Band. Maz. 3:1-9): di dalamnya ada rasa untuk putus asa. ${ }^{79}$ Pemazmur merasa seolah-olah menghadapi ketidakpedulian Tuhan atas penderitaannya, tetapi ia juga mengamati beberapa afirmasi kepercayaan, dan kesimpulannya diselingi dengan janji pujian yang kuat. ${ }^{80}$

Mazmur 13 tetap benar-benar relevan dengan sitz im Leben kontemporer, yang mana memberikan suatu pengajaran bahwa jiwa/ roh tidak dapat segera dipisahkan dan tubuh fisik manusia. Menurut Craigie, "dalam konsepsi Ibrani tidak mungkin ada kehidupan terpisah dari tubuh, karena itu batin seseorang yang sangat dipengaruhi oleh keadaan tubuh fisiknya." ${ }^{11}$ Fakta bahwa orang percaya tidak berarti melarikan diri dari penderitaan, kewajiban, atau kegembiraan kewarganegaraan duniawi. Selanjutnya, Mazmur 13 dan mazmur ratapan lainnya membantu untuk memahami bahwa menghormati Allah memiliki kepentingan pribadi dalam resolusi konflik dan penderitaan. ${ }^{82}$ Pemazmur tidak berseru kepada anugerah Allah, melainkan, ia memohon pada karakter intrinsik Allah seperti yang dijanjikan dan ditunjukkan-Nya melalui hesede-Nya (Band.

Evangelikal: Jurnal Teologi Injili dan Pembinaan Warga Jemaat 1, no. 1 (2017): 79.

${ }^{80}$ Hopkin, "My God, My God, Why Hast Thou Forsaken Me?" Psalm 22 and the Mission of Christ." Christenson, "Parallels between Depression and Lament."

${ }^{81}$ Craigie and Marvin, Word Biblical Commentary, Psalm 1-50, Volume 19, 143.

${ }^{82}$ Lewis Hall, "Suffering in God's Presence: The Role of Lament in Transformation." 
Maz. 46:1-12).83

Mazmur ini juga memberikan implikasi teologis agar memiliki sikap yang tepat untuk bertahan di masa penderitaan: iman yang percaya kepada kasih setia Tuhan. Tokohtokoh dalam Perjanjian Lama (seperti: Ayub, Daud, Elia dan lain-lain) juga memberikan suatu kisah tehadap resolusi atas penderitaan mereka. Begitupun dalam Perjanjian Baru, banyak ayat-ayat yang bersaksi tentang nilai abadi dan ketekunan melalui keadaan-keadaan yang merugikan, beberapa bagian penting termasuk Yohanes 16:33, Filipi 1:27-30, 1 Petrus 1:6-9, 4:12-19, dan Yakobus 1:2-4. Secara ringkas teologi Mazmur 13 sebagai ketabahan dalam penderitaan (yang bisa saja panjang dan tidak cepat berakhir sesuai dengan keinginan), yang tidak terlepas dari nilai-nilai iman dan kepercayaan kepada Tuhan, dan tidak boleh kecut dan putus asa dan tidur sampai mati. Bagaimanapun, kebajikan ini, dapat diperkuat sebagai akibat dari pencerahan pengetahuan, ketika pemazmur paham hukum keadilan Ilahi, sesuai dengan kehendak Tuhan, karena alasan-Nya sendiri, tidak segera memberikan apa yang diminta, dan orang membuat permintaan tersebut harus bertahan, serta memohon untuk tidak kehilangan harapan. Pemazmur mengingat dan mengenal rahmat/kebenaran Allah.

\section{Kesimpulan}

Mazmur 13 merupakan mazmur ratapan pribadi yang memiliki lingkup antara Allah, pemazmur dan musuh, serta mempunyai struktur gramatik (pola $4+4$ dalam ayat-ayat 1 dan 3 , pola $4+3$ dalam ayat 2 dan 4 , dan pola 3 +3 dalam ayat 5) terhadap keyakinanan kepada perjanjian hesed ("kasih setia") Allah. Dengan pendekatan hermeneutik (interpretative design): Eksegesis, artikel ini menemukan adanya pengulangan keluhan pemazmur

\footnotetext{
${ }^{83}$ Desti Samarenna, "Tinjuan Teologi 'Allah Kota Benteng’ Dalam Mazmur 46:1-12,” PASCA : Jurnal
}

sebanyak tiga kali untuk menunjukkan; pertama, ekspresi keputusasaan pemazmur yang menderita berkepanjangan, yang mungkin telah berlangsung untuk beberapa waktu, kedua menjadi bukti bahwa ia sungguh mengharapkan pembebasan dari Allah dapat segera terwujud. Lalu terjadi repetisi kembali tentang penyelamatan Allah sendiri, yang menyelamatkan dari dunia kematian, menerangi mata (ayat 3), dan ketiga melakukan hal-hal yang baik (ay 5b). Hasilnya, ada keyakinan pemazmur yang dinyatakan, yaitu perwujudan kasih setia (hesed ) Allah, sukacita pemazmur, keinginan pemazmur untuk bernyanyi sebagai anugerah dari perbuatan Allah. Mazmur ini merupakan doa yang terpendek dari doa-doa untuk keselamatan dalam Mazmur. Namun ketegasan ini, tidak dapat dianggap sebagai sesuatu yang dangkal.

\section{Kontribusi Penelitian}

Hasil penelitian mengenai repetisi Mazmur 13 memberikan sumbangsih terhadap materimateri kajian Teologi Proper dan kitab-kitab puisi dalam kitab Mazmur yang dapat digunakan dalam pengajaran di kelas STT ataupun dalam kelas-kelas pemahaman Alkitab di gereja. Selain itu, melatih para mahasiswa dan jemaat tentang penggunaan hermeneutika sastra puisi yang berhubungan dengan paralelisme ataupun repetisi, khususnya teksteks ratapan pribadi.

\section{Rekomendasi Penelitian}

Penelitian ini dapat dilanjutkan dalam ruang lingkup sastra puisi Mazmur ratapan pribadi, seperti: hubungan repetisi ataupun paralelisme antar bait (strophe) dalam Mazmur 13 dan Mazmur 22 berkaitan tentang keputusasaan Pemazmur dalam menantikan pertolongan Allah.

\section{Referensi}

Alexander, Joseph Addison. The Psalms Translated

Teologi dan Pendidikan Agama Kristen 15, no. 2 (2019): 15-21. 
and Explained. Grand Rapids: Baker Academic, 1975.

Anderson, Arnold A. The Book of Psalms V. 1 Introduction and Psalms 1-72. Edited by Roland E. Clements. London: Oliphants Marshall, Morgan \& Scott, 1977.

Beckett, Joshua. "Lament in Three Movements: The Implications of Psalm 13 for Justice and Reconciliation.” Journal of Spiritual Formation and Soul Care 9, no. 2 (2016): 207-18. https://doi.org/10.1177/193979091600900206.

Brown, Francis, Samuel Rolles Driver, and Charles Augustus Briggs. A Hebrew and English Lexicon of the Old Testament: With an Appendix Containing the Biblical Aramaic. Peabody: Hendrickson Publishers, 2007.

Broyles, Craig C. The Conflict of Faith and Experience in the Psalms: A Form-Critical and Theological Study. David J. A. Sheffield: A\&C Black, 1989.

Budhi, Samgar Setia. "Eksegesis Mazmur 73: Pergumulan Orang Benar Tentang Kemakmuran Orang Fasik." HUPERETES: Jurnal Teologi Dan Pendidikan Kristen 1, no. 1 (December 14, 2019): 5. https://doi.org/10.46817/huperetes.v1i1.14.

Charney, Davida H. "Performativity and Persuasion in the Hebrew Book of Psalms: A Rhetorical Analysis of Psalms 116 and 22." Rhetoric Society Quarterly 40, no. 3 (2010): 259. https://doi.org/10.1080/02773941003785660.

Christenson, Randall M. "Parallels between Depression and Lament." The Journal of Pastoral Care \& Counseling : JPCC 61, no. 4 (2007): 306. https://doi.org/10.1177/154230500706100402.

Craigie, Peter C, and Tate Marvin. Word Biblical Commentary, Psalm 1-5o, Volume 19. Edited by David A. Hubbard and Glenn W. Barker. Michigan: Zondervan Publishing, 2018.

Daams, Nico. “Translating YHWH Elohim.” The Bible Translator 62, no. 537; Hebrew Bible and its Versions, 6 (2011): 229-31.

https://doi.org/doi:10.1177/02600935110620040 3 .

Dahood, Mitchell J. Psalm I:1-50. Garden City: Doubleday, 1966.

Delitzsch, Franz. Biblical Commentary on the Psalms (Vol. 3). Grand Rapids: William B.

Eerdman's, 1982.

Dolson-Andrew, Stephen L. "An Exegesis of Psalm 13.” CTS Journal 4 (2004): 61.

Gentry, Peter J. “A Preliminary Evaluation and
Critique of Prosopological Exegesis.” The Southern Baptist Journal of Theology 23, no. 2 (2019): 115.

Gesenius, Wilhelm, Emil Kautzsch, and Arthur Ernest Cowley. Gesenius' Hebrew Grammar. Oxford: Courier Corporation, 2006.

Hamilton, Victor P Asherah. In Theological Wordbook of the Old Testament, Ed. R. Laird Harris, Vol. 1, 80-82. Chicago: Moody Press, 1980.

Harris, Robert L. Theological Wordbook of the Old Testament. Chicago: Moody Press, 1981.

Hengstenberg, Ernst. Commentary on the Psalms. Bellingham: Logos Research System, 2010.

Holladay, William L. A Concise Hebrew and Aramaic Lexicon of the Old Testament. Grand Rapids: William B. Eerdman's, 2000.

Hopkin, Shon. "My God, My God, Why Hast Thou Forsaken Me?" Psalm 22 and the Mission of Christ.” Byu Studies Quarterly 52, no. 4 (2013): 23-24.

Koehler, Ludwig, Walter Baumgartner, Johann Jakob Stamm, and Mervyn Edwin John Richardson. The Hebrew and Aramaic Lexicon of the Old Testament. Leiden: EJ Brill, 1994.

Kraus, Hans-Joachim. Psalms 1-59: A Continental Commentary. Minneapolis: Fortress Press, 1993.

Lewis Hall, M. Elizabeth. "Suffering in God's Presence: The Role of Lament in Transformation." Journal of Spiritual Formation and Soul Care 9, no. 2 (2016): 232.

https://doi.org/10.1177/193979091600900207.

Maleachi, Martus Adinugraha. "Karakteristik Dan Berbagai Genre Dalam Kitab Mazmur.” Veritas : Jurnal Teologi Dan Pelayanan 13, no. 1 (2012): 131-32.

https://doi.org/10.36421/veritas.v13i1.250.

Mare, L P. "Psalm 22 : To Pray like Jesus Prayed 1." Old Testament Essays 17, no. 3 (2004): 444.

Martin, Lee Roy. "Lament and Hope in Psalm 130." Pharos Journal of Theology 100, no. 1 (2019): 112.

May, James L. "Expository Articles Psalm 13.” An Epsilon of Room, II, (2011): 279-82. https://doi.org/10.1090/mbk/o77/o1.

Mays, James Luther. Psalms. Louisville: Westminster John Knox Press, 2011.

Mowinckel, Sigmund. Psalm Studies, Volume 1. Atlanta: Society of Biblical Literature, 2014.

Olojede, Funlola. ““...What of the Night?' Theology of Night in the Book of Job and the Psalter." Old Testament Essays 28, no. 3 (2015): 731-32. 
https://doi.org/10.17159/23123621/2015/v28n3a1o.

Prinsloo, Gert T. "Suffering Bodies - Divine Absence: Towards a Spatial Reading of Ancient Near Eastern Laments with Reference to Psalm 13 and an Assyrian Elegy (K 890)." Old Testament Essays 26, no. 3 (2013): 773-803.

Rame, Gustav R. "Mneyembah Tuhan: Suatu Studi Exegetis Mazmur 100.” Missio Ecclesiae 4, no. 2 (2015): 111-12.

Ross, Allen P. A Commentary on the Psalms. Grand Rapids: Kregel Academic, 2011.

Samarenna, Desti. "Tinjuan Teologi 'Allah Kota Benteng' Dalam Mazmur 46:1-12.” PASCA : Jurnal Teologi Dan Pendidikan Agama Kristen 15, no. 2 (2019): 15-21.

https://doi.org/10.46494/psc.v15i2.53.

Sparks, Kent. "The Psalm: Strophic Structure and Theological Commentary." Journal of Near Eastern Studies 66, no. 3 (2007): 210-12. https://doi.org/https://doi.org/10.1086/52176o.

Staton Jr, Cecil P. “'How Long, O Yahweh?’ The Complaint Prayer Of Psalm 13." Faith and Mission 07, no. 02 (1990): 61.

Suryaningsih, Eko Wahyu. "Doktrin Tritunggal Kebenaran Alkitabiah." PASCA : Jurnal Teologi dan Pendidikan Agama Kristen 15, no. 1 (2019): 20. https://doi.org/10.46494/psc.v15i1.64.

Stott, Douglas W, G Johannes Botterweck, Helmer Ringgren, and Heinz-Josef Fabry. Theological Dictionary of the Old Testament. Grand Rapids: Wm. B. Eerdmans Publishing, 2003.

Tua, Eko Mulya. “Respon Daud Dalam Menghadapi Pergumulan: Studi Terhadap Kitab Mazmur 3:1-9." Evangelikal: Jurnal Teologi Injili Dan Pembinaan Warga Jemaat 1, no. 1 (2017): 79. https://doi.org/10.46445/ejti.v1i1.59.

Tucker, W. Dennis. "Is Shame a Matter of Patronage in the Communal Laments?” Journal for the Study of the Old Testament 31, no. 4 (2007): 469.

https://doi.org/10.1177/0309089207080057.

Wendland, Ernst R. "Poeticizing the Psalter in an African Language: From Poetry into Poetry, With Special Reference to Psalm 13- 'How Long, O Lord...!"' Open Theology 2, no. 1 (2016): 165-78. https://doi.org/10.1515/opth-2016-0013.

Westerman, Claus. Praise and Lament in the Psalms. Atlanta: Westminster John Knox Press, 1981.
Zaluchu, Sonny Eli. "Strategi Penelitian Kualitatif Dan Kuantitatif Di Dalam Penelitian Agama." Evangelikal: Jurnal Teologi Injili Dan Pembinaan Warga Jemaat 4, no. 1 (2020): 35. https://doi.org/10.46445/ejti.v4i1.16 